\title{
Presença da ficção científica em Portugal: o embate entre Fernando Pessoa e José Saramago
}

\author{
Ermelinda Maria Araújo Ferreira \\ Universidade Federal de Pernambuco
}

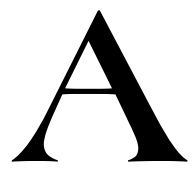

pesar de a crítica raramente identificar nos estudos sobre os modernistas portugueses qualquer vínculo formal com a ficção científica, é inegável que alguns autores considerados clássicos da contemporaneidade, e perfeitamente integrados aos cânones convencionais, exercitaram efetivamente este gênero de escritura. Dedicaremos à análise comparativa dos princípios contraditórios presentes em algumas obras de dois desses avatares - Fernando Pessoa e José Saramago - algumas páginas a seguir, com o intuito de assinalar a precursividade canônica deste gênero tido como paraliterário e menor, e que curiosamente parece tão desprestigiado e esquecido pela literatura em língua portuguesa nos dois lados do Attântico, em pleno século XXI.

Causa estranhamento que, numa época mundialmente atingida por profundas transformaçôes nas áreas da ciência e da tecnologia, as literaturas desses dois países se conservem tão indiferentes a esses questionamentos, e se mantenham tão aferradas a uma abordagem sociológica essencialmente fisiológica da miséria humana. No claustrofóbico espaço de um neorealismo utópico de validade vencida, continua-se a assistir, nas literaturas portuguesa e brasileira - com raras exceçóes - a um marasmo criativo no que diz respeito aos gêneros. Volta e meia esse marasmo se traduz na opção por uma literatura de denúncia e de suposta intervenção salvacionista, que ora insiste na reedição da fórmula de sucesso de um regionalismo fossilizado, 
ora se converte numa versão urbanizada, também excessivamente desgastada desta mesma abordagem, com ênfase na denúncia indignada ou na descrição complacente, quando não conivente, da violência e da crueldade do cotidiano das cidades grandes. Pouco espaço é conferido ao fantástico, e menos ainda à literatura especulativa.

Mas ao contrário do que possa parecer, elementos do gênero ficção científica visitaram os grandes textos da literatura portuguesa e brasileira, ainda que timidamente, ao longo da modernidade. No caso da literatura portuguesa, houve mesmo uma inclinação deliberada dos dois principais expoentes do Modernismo - em Portugal designado como Futurismo pelos gêneros paraliterários em suas produções. Fernando Pessoa, com sua formação em língua inglesa e sua admiração incondicional por Edgar Allan Poe, estreou na literatura com o propósito de escrever novelas policiais, originalmente o gênero especulativo por excelência, já que se baseava no princípio da decifração intelectual de um enigma, e não no da exposição vulgar da violência, aspecto que se tornou dominante com o tempo. E Mário de Sá-Carneiro, com uma formação mais francesa, produziu durante sua curta existência uma obra de ficção marcadamente fantástica, enveredando mesmo pelas conjecturas típicas da narrativa de ficção científica.

Ainda que a fortuna crítica em torno de suas produções não costume abordar o tema, é notável como a aguda consciência de Pessoa e SáCarneiro sobre as questôes prementes do mundo em transformação nas primeiras décadas do século XX transparece no âmago da poesia de ambos. As principais interrogações do gênero paraliterário em questão são abordadas, em particular a dúvida sobre a natureza do humano, que gera o tema do duplo, definitivo para os dois poetas. A reflexão sobre a validade das conquistas tecnológicas é o

grande mote do único livro publicado por Pessoa em vida Mensagem -, que ao tentar resgatar Os Lusíadas do fosso de sua condenação a uma quase ilegibilidade pós-descolonizadora atribui ao impulso da aventura do humano rumo ao desconhecido o grande valor transcendendal deste épico, resguardando-o das críticas mais ferrenhas ao seu discurso 
imperialista e bélico, impermeável à percepção do outro. A atmosfera cósmica e mística que cerca Mensagem torna possível a sua leitura como uma obra de ficção científica erudita, até mesmo hermética, que muitas vezes parece interrogar as razões de outras viagens iniciáticas do humano, como as viagens espaciais, cujos ecos podem ser ouvidos nos implícitos e nas entrelinhas de seus versos.

Além de ser o autor do único exemplar verdadeiramente $s c i-f i$ da produção dos primeiros modernistas portugueses, com o seu conto "A estranha morte do professor Antena”, uma versão do clássico $A$ máquina do tempo, de H. G. Wells, Mário de Sá-Carneiro terá sido, provavelmente, um teórico visionário da era virtual no contexto da confraria de Orpheu. Em sua obra percebe-se toda uma teorização sobre o assunto, com textos muito específicos abordando temas tão contemporâneos quanto a virtualização do corpo - que permeia uma inusitada obra poética totalmente centrada na rejeição da imagem pessoal -, abrindo espaço para especulações como as possibilidades de reconstrução cosmética e estética da auto-imagem pela medicina, através da reconfiguração intervencional e protética do corpo. Também se encontra uma teorização sobre a virtualização do texto - com a dissolução das palavras em hipertextos multimídia dispersos num meio digital e impalpável, objetivo máximo de seu alter-ego, o poeta Zagoriansky, que no estranhíssimo conto Asas elabora os preceitos de uma arte imune aos princípios da gravidade. Uma arte multimodal - possível, hoje, no ambiente virtual da hipermídia:

Uma arte gasosa... poemas sem suporte... flexíveis...que se podem deslocar em todos os sentidos...Uma Arte sem articulações!...Sons interseccionados, planos cortados, múltiplos planos!...Tudo se trespassará, se esgueirará, perpetuamente variável, ondulante - mas, em somatório, sempre o mesmo conjunto!... ${ }^{1}$

${ }^{1}$ SÁ-CARNEIRO, 1995, p. 492. 
Se nos debruçarmos sobre a produção de Pessoa e Sá-Carneiro com um olhar investido das mais recentes teorizações sobre ciência e arte, talvez cheguemos mesmo à conclusão de que a dupla portuguesa dos modernistas editores de Orpheu produziu uma vasta e consistente obra de ficção científica, de caráter visionário, quando não premonitório, embora sem o apelo popular que costuma caracterizar o gênero sobretudo na sua versão americana. Nas versões européias o fenômeno da mercantilização do gênero parece não ocorrer com tanta força, talvez porque pese sobre essas produçôes não o impulso de divulgar ou vulgarizar a pesquisa científica, muitas vezes incipiente ou inexistente no contexto de onde surgem esses escritos; e sim o impulso de promover uma especulação de ordem mais filosófica, existencial e psicológica - profundamente literária, portanto, onde o imaginário adquire um papel decisivo, e não muito distante do que deverá assumir no âmbito da própria ciência, antes de o homem partir para concretizar, empiricamente, os seus sonhos.

Dos prováveis herdeiros dessa possível inclinação futurista, no sentido $s c i-f i$, dos criadores de Orpheu, selecionamos para uma breve explanação alguns textos da figura mais destacada das letras portuguesas na atualidade: José Saramago. Autor de uma obra celebrada sobretudo pelo resgate histórico do passado e da tradição, e pelo seu vínculo político resistente com o pensamento socialista, Saramago será talvez o escritor português recente que mais insistentemente tem colocado em pauta e transformado em tema de suas obras as angústias típicas que rondam a literatura de ficção científica. Não por acaso datam de seus anos de formação produçōes deliberadamente afeitas ao gênero, como a coletânea de contos Objecto Quase e o indefinível livro O ano de 1993-de profunda influência nas suas produçóes posteriores - que pretendemos considerar no decorrer deste ensaio. Ao contrário do entusiasmo presente nos neoutopistas Pessoa e Sá-Carneiro, a ficção de Saramago opta pela distopia, num confronto direto e ferrenho com a obra dos precursores, que pode lançar luzes interessantes e estimulantes ao debate crítico. 


\section{Fernando Pessoa: tudo vale a pena se a alma não é pequena}

Venho de longe e trago no perfil,

Em forma nevoenta e afastada, O perfil de outro ser que desagrada Ao meu atual recorte humano e vil.

Fernando Pessoa

The Beat writer Alexander Trocchi once memorably proclaimed himself to be a 'Cosmonaut of inner space'. It's a title of which Pessoa - perhaps the finest 20th-century chronicler of all the nooks and crannies of consciousness, dreams, and identity - is far more deserving.

Jerome-Boyd Maunsell

É curioso que Fernando Pessoa, um poeta moderno, irônico e lúcido como nunca se viu, tenha levado a vida a escrever Mensagem, um livro passadista, que parece atormentá-lo com a necessidade de responder à indagação camoniana posta na fala do Velho do Restelo em Os Lusíadas: "Valeu a pena?". ${ }^{2}$ Consciente de que as transformaçōes políticas e o desastroso custo social das navegações portuguesas do século XVI levariam a uma condenação da empresa que motivou o grande épico, Pessoa dedicase a compor uma epopéia lírica da modernidade, cuja maior proposta será a de responder afirmativamente a Camóes e ao seu personagem, resgatando

${ }^{2}$ Questão central em Os Lusíadas, a frase encontra-se no décimo poema da segunda parte de Mensagem, com o título: "Mar português": "Ó mar salgado, quanto do teu sal/São lágrimas de Portugal!/Por te cruzarmos quantas mães choraram,/Quantos filhos em vão rezaram!/Quantas noivas ficaram por casar/ Para que fosses nosso, ó mar!/Valeu a pena? Tudo vale a pena/Se a alma não é pequena./Quem quer passar além do Bojador/Tem que passar além da dor./ Deus ao mar o perigo e o abismo deu,/Mas nele é que espelhou o céu."; e dialoga com o episódio do Velho do Restelo, no Canto IV do épico camoniano. 
n'Os Lusiadas, para além do impulso imperialista e bélico que despreza, a expansão da alma humana que vislumbra como o principal resultado dos arroubos da ciência. Pois foi a ciência náutica, o domínio da linguagem das estrelas, a curiosidade especulativa sobre o horizonte além-mar o que motivou o humano - que Pessoa adjetiva "português" - a arriscar-se nos espaços desconhecidos do oceano, para descobrir-se outro, cada vez mais, cada vez mais longe de si mesmo.

Encontra-se em Mensagem, portanto, uma entusiástica defesa da ciência, em benefício da qual todos os sacrifícios são justificados, pois o conhecimento não se adquire sem dor e sem perdas. $\mathrm{Na}$ concepção pessoana, "humano" é o louco que deseja grandeza qual a sorte a não dá, e isto é o que o diferencia dos demais exemplares da espécie, presos aos ditames de seus corpos e sumariamente definidos como "cadáveres adiados que procriam”. O que Pessoa celebra n'Os Lusiadas, e que o consome ao longo dos anos de dedicação à obra Mensagem, publicada em 1934 (um ano antes de sua morte), é o impulso da superação humana para além de todos os medos, rumo a uma até então impensável concepção do planeta: "E viu-se a Terra inteira, de repente/Surgir, redonda, no azul profundo". Afirmação que nada deixa a dever, e mesmo antecipa o deslumbramento de Gagárin, quase trinta anos depois, ao projetar-se fora da atmosfera numa cápsula e contemplar sua morada de uma perspectiva radicalmente diversa: "A Terra é azul" ${ }^{3}$

Desde então, a vertiginosa incorporação dos avanços tecnológicos ao cotidiano das pessoas e o estreitamento das ditas "interfaces" homem-

${ }^{3}$ Yuri Gagárin, cosmonauta russo, foi o primeiro homem a viajar pelo espaço. Em 1961, a bordo da cápsula espacial Vostok I, realizou pela primeira vez na história um vôo em órbita da Terra, numa missão que durou cerca de uma hora e meia. Iria viver um sonho inspirado sessenta anos antes pelo cientista russo Constantin Tsiolkowsky, que no início do século XX já havia arquitetado a base da astronáutica moderna. Durante a Segunda Guerra Mundial, a tecnologia se juntaria à teoria e Gagárin se tornaria tão importante quanto Cristóvão Colombo. 
máquina têm resultado em novas viagens e numa imprevisível concepção de "navegação", que já não se faz para fora, mas para dentro do ser, enquanto simula mergulhar num espaço forjado e artificial: o ciberespaço. Os "mares nunca dantes navegados" de hoje, portanto, são menos os de uma geografia física do que os de uma geografia psíquica, e produzem alterações comportamentais e sociais tão profundas que têm gerado um ruído no âmbito da crítica sobre a própria natureza do "humano" na atualidade.

Autores como Gilles Deleuze, em O corpo sem órgãos; Jean-François Lyotard, em $O$ inumano; e Donna Haraway, em Manifesto cyborg, por exemplo, apontam para certa tendência histórica, transfigurada nos mecanismos de modernização tecnológica, de redefinição do "humano" a partir da máxima cartesiana - "Cogito ergo sum" ("Penso, logo existo"). Quanto mais se distancia da necessidade de sua corporalidade como elemento de identificação, mais o "humano" se projeta na mente, e projeta meios de se libertar do corpo como elemento aprisionador, suscetível à dor, à corrupção e à morte. $\mathrm{O}$ sonho da vida eterna adquire a perspectiva da eternização do conteúdo mental subjetivo (conhecimento e memória) em qualquer suporte físico: não importa se o do clone orgânico que duplica as próprias células de seu velho corpo, ou o do computador no qual seria feito o download de sua identidade. ${ }^{4}$ A ficção científica diverte-se explorando essas possibilidades, que a cada dia tornam-se mais plausíveis, acompanhando o ritmo da ciência que progride a passos largos.

Cresce, portanto, o impasse sobre o que é o "humano", um impasse que problematiza profundamente a questão do corpo e que abre espaço para teorias em torno de um conceito ainda não legitimado pela academia, mas já muito veiculado pela ficção: o do "pós-humano". Segundo Jair Ferreira dos Santos, "pós-humano” é um neologismo cunhado ou

${ }^{4}$ Hans Moravec, pesquisador americano na área da robótica e autor do livro Mind Children, afirma que em 2040 os computadores atingirão a mesma capacidade de processamento do cérebro humano. Segundo ele, a informação contida num cérebro poderá ser descarregada num computador, num passaporte para a imortalidade. 
veiculado pelo intelectual Ihab Hassan no ensaio "Prometeus as performer: toward a posthumanist culture?, de 1977, que retomava o parágrafo final do livro de Michel Foucault, As palavras e as coisas, no qual se previa com chocante serenidade o desaparecimento do humano. Para Santos, "o póshumano, se ainda não adquiriu densidade nem credibilidade como idéia descritiva ou explicativa, pelo menos tem o mérito de haver incluído no debate filosófico a ficção científica, um gênero popular e fantasioso, porque é nele que se podem detectar as visões, os terrores em pulsação no imaginário coletivo". 5

Katherine Haylescomenta queaficçáo científica explorapossibilidadesinscritas na "condição pós-humana", particularmente os estragos que a homologia entre a informação computacional e a cerebral deixam entrever, e que evocam sérias transformaçóes na subjetividade. No lugar do sujeito liberal humanista e de sua identidade livre, consciente, racional, autônoma, com um ego estável, começa a despontar o sujeito pós-humano, "um amálgama, uma coleção de componentes heterogêneos, uma entidade materialinformacional cujas fronteiras estão submetidas à contínua construção e reconstrução". ${ }^{6}$

A heteronímia pessoana, constituindo-se como uma subjetividade pulverizada numa multiplicidade de "eus à deriva", corpoemas onde as idéias são transformadas em seres imaginários, seres virtuais, já apontava para essa fragilidade da consciência posta em destaque na era da convergência geral dos organismos com as tecnologias, e que está levando o entendimento sobre o ser humano a uma reconfiguração sem precedentes. A verdade torna-se a cada dia uma mera questão de ponto de vista, ou de perspectivas que se expandem continuamente, relegando as crenças mais arraigadas à condição de ficções forjadas e provisórias.

Esse debate talvez possibilite uma releitura de algumas consideraçóes politicamente incorretas - segundo a perspectiva do pensamento ainda

${ }^{5}$ SANTOS, 2003, p. 79.

${ }^{6}$ HAYLES, 1999, p. 4. 
dominante neste início de século XXI - do filósofo pessoano ultra-futurista Antonio Mora, para quem "uma época é um estado mental" e "a religião é a média desse estado mental para a coletividade". Defensor do paganismo, que define como "o correspondente religioso da era científica" ("Paganism as corresponding to the religion for a scientific age"), ele diz:

Mas, de comum, nós, neopagãos portugueses, rejeitamos a obra cristã por completo, na sua forma direta, e nas suas formas indiretas. Assim, rejeitamos: a democracia, todas as formas de governo não-aristocrático, todas as fórmulas humanitárias, todas as fórmulas de desequilíbrio como, por exemplo, o imperialismo germânico ou a democracia aliada; rejeitamos o feminismo, porque pretende igualar a mulher ao homem e conceder à mulher direitos políticos e sociais, quando a mulher é um ser inferior apenas necessário à humanidade para o fato essencial mas biológico apenas da sua continuação, rejeitamos as ternuras anticientíficas, como o vegetarianismo, o antialcoolismo, o antivivisseccionismo, não admitindo direitos aos animais inferiores ao homem.(...). ${ }^{8}$

A mera leitura dessa passagem poderia dar a idéia de um exemplar discurso reacionário e antiquado, avesso à modernidade e às conquistas do progresso. Mas o mesmo trecho termina com a frase: "Povo

7 "A única força verdadeira e segura do mundo moderno é a ciência positiva. A ciência objetiva - eis o novo elemento de equilíbrio da subjetividade liberta, que entrou no mundo. Para se tornar um princípio deveras preponderante falta à ciência que saia na verdade dos laboratórios e das cátedras, e se humanize. Ora a humanização suprema é a religião, e para um princípío se tornar condutor de uma sociedade e deveras representativo dela, tem de tornar-se sua religião. Uma religião provinda da ciência, que é essencialmente objetiva, tem de ser uma religião absolutamente objetiva. A pura religião objetivista é o paganismo. Por onde se descobre que, com o acréscimo do valor da ciência, com o alargamento de suas conquistas e o alastre da sua técnica mental, o paganismo começa a renascer." Antonio Mora. Esfacelamento do Cristismo, p. 198.

${ }^{8}$ PESSOA, 2005, p. 171. 
conservador, povo morto". É difícil analisar o pensamento pessoano exatamente porque ele não é uniforme e coerente, e porque se pulveriza entre figuras igualmente contraditórias; unidas, talvez, apenas pela ironia que fundamenta a obra pessoana:

Por ironia entende-se, não o dizer piadas, como se crê nos cafés e nas redaçôes, mas o dizer uma coisa para dizer o contrário. A essência da ironia consiste em não se poder descobrir o segundo sentido do texto por nenhuma palavra dele, deduzindo-se porém esse segundo sentido do fato de ser impossível dever o texto dizer aquilo que diz. Assim, o maior de todos os ironistas, Swift, redigiu, durante uma das fomes na Irlanda, e como sátira brutal à Inglaterra, um breve escrito propondo uma solução para essa fome. Propõe que os irlandeses comam os próprios filhos. Examina com grande seriedade o problema, e expõe com clareza e ciência a utilidade das crianças de menos de sete anos como bom alimento. Nenhuma palavra nessas páginas assombrosas quebra a absoluta gravidade da exposição; ninguém poderia concluir, do texto, que a proposta não fosse feita com absoluta seriedade, se não fosse a circunstância, exterior ao texto, de que uma proposta dessas não poderia ser feita a sério. ${ }^{9}$

Defendida pelo poeta como o valor máximo da criação, a ironia é continuamente exercitada na prática heteronímica, e provavelmente orienta o discurso de Mora. Aliás, Pessoa, Caeiro, Reis e Mora, que se dizem "neopagãos portugueses", não concordam entre si sobre os princípios do neopaganismo. Caeiro é o poeta da natureza; um filósofo sem formação acadêmica e que não se reconhece filósofo, mas apenas um pastor. $\mathrm{O}$ intelectual Mora, entretanto, ao prefaciar os poemas de Caeiro, valoriza na sua personalidade não o apreço à simplicidade pastoril, mas a sofisticação de sua mente, a objetividade de sua visão, essenciais à atividade científica que entende como primordial sobre todas as outras formas de atividade. A ciência é o "vero imo templo, o sumo trono dos espíritos de hoje". ${ }^{10}$ É

\footnotetext{
${ }_{9}^{9}$ PESSOA, 2005, p. 337.

${ }^{10}$ PESSOA, 2005, p. 210.
} 
à defesa dessa "aristocracia espiritual" que Mora parece almejar quando ataca todos os sistemas de governo e todas as formas de organização social "nãoaristocráticas". O que há de "monárquico" em Pessoa também é relativizado por Mora em seu discurso. Por isso, ao analisar as causas da repulsa de seu tempo à ciência, Mora explica o caráter "reacionário" do neopaganismo como um processo de "desadaptação" à realidade vigente:

Parecerá, à primeira vista, que são reacionários, muito simplesmente, os sistemas que advoguem, por exemplo, o absolutismo régio. $\mathrm{O}$ absolutismo régio é, porém, apenas um tipo desses sistemas. A essência deles é outra. Se alguma coisa a ciência impõe, como base política, é que se repare nas divergências nacionais, criadas primeiro por uma situação geográfica, segundo por situação histórica. Tudo quanto reaja contra esta tese é reacionário em política. Uma outra coisa que a ciência impõe, neste campo: a necessidade da adaptação ao meio, que é o teor geral da civilização. Assim, ao passo que faz assentar a tese política em um nacionalismo científico, por outro faz assentar essa tese em um internacionalismo igualmente científico, representando a adaptação desse nacionalismo ao espírito de época. ${ }^{11}$

Exemplo desta adaptação estaria, talvez, na concepção de "pátria" extraída da Mensagem: "Minha pátria é a língua portuguesa”. Da mesma maneira, a rejeição às "fórmulas humanitárias" se compreende como uma rejeição ao cristismo. Para Mora: "O humanitarismo é o último baluarte da doutrina cristã. $\mathrm{O}$ mal cristão existe ali, em toda a plenitude de sua maleficência." 12 E isso não exatamente pelos valores cristãos em si, mas porque a mentalidade da Igreja Católica, sobretudo em Portugal, ofereceria um entrave à disseminação da ciência, representando um atraso ao desenvolvimento da humanidade:

Necessariamente fria e dura nas suas apreciações, a ciência vai de encontro às várias formas de sentimentalidade que constituem o fundo

\footnotetext{
${ }^{11}$ PESSOA, 2005, p. 208.

12 PESSOA, 2005, p. 208.
} 
moral do cristismo. Necessariamente nos seus intuitos, pois os seus resultados aplicados beneficiam materialmente a humanidade, e a atitude mental que deriva de sua prática torna inaptos os seus práticos a olharem acima da humanidade objetiva, vai de encontro a quanta teorização especificamente transcendente caracteriza a metafísica cristista. ${ }^{13}$

Enquanto compreende o seu tempo como inadaptado à ciência, à "religião científica" que diz professar (o neopaganismo) e até à "arte científica" ("a religião é a forma social da arte") ${ }^{14}$, Antonio Mora torna-se o porta-voz da inadaptação pessoana ao seu próprio tempo, de onde advém a dita "indiferença estóica" das atitudes de seus heterônimos e de sua obra. Trata-se, portanto, não de um impulso reacionário, mas o contrário. $\mathrm{O}$ poeta sente-se tão adiante de sua época que não a reconhece como tal, e nem vê uma possibilidade de nela intervir. Daí a afirmação:

Nós realizamos, modernamente, o sentido preciso daquela frase de Voltaire, onde diz que, se os mundos são habitados, a terra é o manicômio do Universo. Somos, com efeito, um manicômio, quer sejam ou não habitados os outros planetas. Vivemos em doença crônica e o nosso destino é o de não morrer por nos termos adaptado ao estado de perpétuos moribundos. ${ }^{15}$

${ }^{13}$ PESSOA, 2005, p. 210.

14 "A frase profunda de Goethe - que pode dispensar a religião aquele que tem a ciência e a arte, mas não quem as não tem - tem, no fundo, esta significação muito simples: quem não pode ter uma arte superior, que tenha uma arte inferior. (Ou, propriamente, não será a religião a base indiferenciada da arte, da ciência e da moral?)”. PESSOA, 2005, p. 209.

15 "Que pode ter com uma época destas um espírito da raça dos construtores, uma alma filha das grandes verdades do paganismo? Nada, salvo a repulsa espontânea, o desprezo refletido. Somos, assim, nós que somos os únicos a discordar da decadência, compelidos a tomar uma atitude que é, de sua natureza, decadente também. Uma atitude de indiferença é uma atitude decadente, e nós somos obrigados a uma atitude de indiferença pela incapacidade de nos 
Mas Pessoa parece antecipar todas as críticas que o futuro poderia fazer ao seu pensamento reacionário/progressista ao pulverizar suas idéias em níveis de gradação. Assim, a indiferença do credo neopaganista não é a mesma e não tem o mesmo valor para todas as suas personalidades literárias. O próprio Caeiro, mestre dos heterônimos, adoece e sucumbe, a certa altura de sua obra, ao subjetivismo amoroso, próprio do "cristismo". Em seu prefácio a Oguardador de rebanhos, Ricardo Reis ataca impiedosamente essa fraqueza:

Eu perdoaria ao poeta que ele houvesse assim permanecido ainda escravo de certos apetrechos sentimentais da mentalidade cristista, se ele nunca, até ao fim da obra, se conseguisse libertar deles. Mas se, a dada altura da sua evolução poética, ele o fez, culpo-o, e severamente o culpo (como severamente, em pessoa, o culpei) de não se voltar aos seus poemas anteriores, ajustando-os à sua disciplina adquirida, e, se alguns a essa disciplina não se sujeitassem, riscando-os completamente. ${ }^{16}$

Além de ser curioso que Caeiro não tenha, deliberadamente, riscado esses versos de sua obra (o que fala da persistência de uma dúvida em sua alma, contrária às certezas absolutas de Reis), chama a atenção que o próprio Mora discorde da postura do poeta médico e monarquista, ao falar sobre o paganismo:

Aceito como tal esta atitude nossa, mas não aceito o modo como a aceita Ricardo Reis. Quero que sejamos indiferentes para com a época que nada pode querer de nós, e sobre a qual em nada podemos agir. Mas não quero que se cante essa indiferença como coisa boa de per si. É isso que faz Ricardo Reis. Por esse ponto, longe de tornar-se indiferente às

adaptarmos a um meio como este. Não nos adaptamos, porque os sãos se não adaptam a um meio mórbido. Não nos adaptando, somos mórbidos. Neste paradoxo, nós, os pagãos, vivemos. Não temos outra esperança nem outro remédio." PESSOA, 2005, p. 212.

${ }^{16}$ Introdução aos poemas completos de Alberto Caeiro, por Ricardo Reis. In: PESSOA, 1986, p. 135. 
correntes da época, integra-se em uma delas, que é a decadente. Essa indiferença é já uma adaptação ao meio. É já uma concessão. ${ }^{17}$

Se admitirmos que a violência contra os mais caros valores humanistas presente na afirmação de Antonio Mora pode ser lida numa perspectiva irônica, talvez possamos interpretá-la (ou superinterpretá-la) como a expressão antecipada, e implícita, de valores "pós-humanistas". Para os teóricos dessa vertente, a "nova condição humana", resultante de nossa relação promíscua com as máquinas de produção, consumo, ciência, protética, já não encontraria respaldo na razão iluminista, na afirmação do homem como princípio e centro de tudo. No final do século XX, segundo Donna Haraway, esse "homem" tornou-se uma quimera, um híbrido teorizado e fabricante de máquina e organismo: um cyborg. $\mathrm{O}$ cyborg - contração em inglês de cybernetic organism - eliminaria muitos dos discursos aos quais nos aferramos em nossa presente condição. Se caminhamos - ou já nos constituímos como cyborgs -, precisamos encarar de fato a superação das categorias do humanismo, para o qual o indivíduo, isolado nas fronteiras do corpo, é uno na sua identidade e habita uma interioridade cuja distinção é a autonomia.

Como diz Jair Ferreira dos Santos, o cyborg é a "primeira criatura pós-metafísica, que por sua condição híbrida e conectiva não cultiva o drama edípico, não aspira à salvação, não sacraliza a subjetividade, pelo contrário, acata as identidades fraturadas ou o vazio de identidade que vagueia ao sabor de personificações pontuais" ${ }^{18}$ Para um cyborg, sistemas religiosos, políticos e sociais humanos, ou melhor: humanistas, não fazem sentido algum. Segundo Paula Sibilia, a sociedade atual assiste ao surgimento de um tipo de saber radicalmente novo:

Fáustico, ele pretende exercer um controle total sobre a vida, superando as suas limitaçôes biológicas; inclusive, a mais fatal de todas: a mortalidade. Nos discursos da tecnociência contemporânea, o "fim da

${ }_{17}$ PESSOA, 1986, p. 212.

${ }^{18}$ SANTOS, 2003, p. 62. 
morte" parece extrapolar todo substrato metafórico para apresentar-se como um objetivo explícito: as tecnologias da imortalidade estão na mira de várias pesquisas atuais, da inteligência artificial à engenharia genética, passando pela criogenia e por toda a farmacopéia antioxidante. ${ }^{19}$

Num mundo onde a morte estaria se tornando "uma estratégia evolutiva ultrapassada", códigos de ética religiosos não dariam conta dos desafios existenciais de seres que já não se concebem como corpos e almas, mas como padrões de informação. Para estes seres, sistemas de governo "humanos" também estariam datados. Tanto os totalitarismos quanto as democracias lidariam com critérios hierárquicos improcedentes: daí, talvez, a defesa da "aristocracia" de uma entidade híbrida e mutante como o cyborg, que passaria a imperar no contexto atual, bastante distinto daquele que serviu de cenário à sociedade industrial. Pois, como diz Sibilia:

Assistido pelo poder de processamento do instrumental digital, o novo capitalismo metaboliza as forças vitais com uma voracidade inaudita, lançando e relançando ao mercado, constantemente, novas formas de subjetividade que serão adquiridas e de imediato descartadas pelos diversos targets aos quais são dirigidas, alimentando uma espiral de consumo de modos de ser em aceleração crescente. Assim, a ilusão de uma identidade fixa e estável, característica da sociedade moderna e industrial, vai cedendo terreno aos "kits de perfis padrão" ou "identidades prêt-à-porter". ${ }^{20}$

Que o discurso pessoano, pulverizado nos discursos dos heterônimos, nos habilita a supor que ele já nos falava de uma "condição pós-humana" e que já se punha no lugar do cyborg parece provável, sobretudo se entendemos o cyborg como a encarnação de um futuro aberto às ambigüidades e diferenças. Em um mesmo corpo reúnem-se o mecânico e o orgânico, a cultura e a natureza, o simulacro e o original, a ficção

\footnotetext{
${ }^{19}$ SIBILIA, 2002, p. 50.

${ }^{20}$ SIBILIA, 2002, p. 33.
} 
científica e a realidade social. Segundo Lucia Santaella, a declaração de Haraway de que somos todos cyborgs deve ser tomada em sentido literal e metafórico: "No sentido literal, porque as tecnologias biológicas e teleinformáticas estão, de fato, redesenhando nossos corpos. Metaforicamente, porque estamos passando de uma sociedade industrial orgânica para um sistema de informação polimorfo." ${ }^{21}$

Profundamente irônico, Antonio Mora seria, assim, a encarnação do sacerdote pós-humano, impermeável ao humanismo em quaisquer de suas versóes: seja a religiosa, seja a política, seja a estética. Numa verdadeira provocação aos discursos humanistas, ele fala de "Homens", "Mulheres" e "Animais" como conceitos superados, que traduzem hierarquias filosóficas construídas sobre critérios de verdade pré-estabelecidos, baseados em sistemas simbólicos fundados em oposiçôes binárias: corpo/ alma, alter/ego, matéria/espírito, emoção/razão, homem/mulher, humano/animal, natural/artificial. Num mundo de cyborgs, estruturado sobre critérios alheios a esses maniqueísmos obsoletos, que lugar teriam, entre outras, as lutas políticas "feministas" e "ambientalistas" - se os sujeitos dessas lutas já não existiriam?

O incômodo radicalismo do discurso de Mora, que parece valer menos pelo que simula professar e mais pelo que denuncia nas suas entrelinhas, nos leva a pensar se ainda é válido - ou sequer desejável persistir dentro das margens tradicionais do conceito de "homem". Não seria preciso, talvez, reformular essa noção herdada do humanismo liberal e inventar outras formas, capazes de conter as novas possibilidades que estão se abrindo? Para Sibilia: “' 'O que é aquilo que estamos nos tornando?' e 'O que gostaríamos de nos tornar?' são perguntas de alto conteúdo político, cujas respostas não deveriam ser dadas ao acaso".

Ciente disso, o "neopaganismo português" pessoano pregaria, pelo viés irônico tão caro ao poeta, uma outra realidade concebida a partir da idéia de um outro ser: seria, talvez, a expressão de uma filosofia nova num mundo novo - um mundo que, nos discursos de Mora, se nos afigura

${ }^{21}$ SANTAELLA, 2003, p. 186. 
estranhamente distópico, como uma projeção fantástica ou de ficção científica, mas que certamente seria mais familiar a Fernando Pessoa - o "cosmonauta do espaço interior" - do que o mundo da realidade imediata.

\section{José Saramago: aqui o mar acaba e a terra principia}

Fala do Velho do Restelo ao Astronauta

Aqui, na Terra, a fome continua, A miséria, o luto, e outra vez a fome. Acendemos cigarros em fogos de napalme. E dizemos amor sem saber o que seja. Mas fizemos de ti a prova da riqueza, E também da pobreza, e da fome outra vez. E pusemos em ti sei lá bem que desejo De mais alto que nós, e melhor e mais puro. No jornal, de olhos tensos, soletramos As vertigens do espaço e maravilhas: Oceanos salgados que circundam Ilhas mortas de sede, onde não chove. Mas o mundo, astronauta, é boa mesa Onde come, brincando, só a fome, Só a fome, astronauta, só a fome, E são brinquedos as bombas de napalme.

Os poemas possiveis, José Saramago

Confrontar o poema "Fala do Velho do Restelo ao Astronauta", de José Saramago, com o poema "Mar Português", de Fernando Pessoa, mostra o quanto ambos estão sintonizados numa interpretação da epopéia camoniana que privilegia a percepção dos efeitos dos avanços científicos e tecnológicos no processo de transmutação do ser humano. Sintonizar, evidentemente, não quer dizer concordar, porque não há acordos entre Saramago - na sua encarniçada luta revisionista com o seu precursor pela busca de auto-afirmação, como diria Harold Bloom - e Pessoa, contra quem chega a atentar de forma homicida no romance $O$ ano da morte de Ricardo Reis, na figura de seu heterônimo mais etéreo, ausente e 
"desumano". Menos um estóico clássico - como costuma ser interpretado - do que um andróide melancólico, Ricardo Reis será a imagem de Pessoa que mais profundamente despreza o seu "atual recorte humano e vil", e talvez a que melhor canta o advento de um novo ser em versos futuristas ainda incompreensíveis, em muitos aspectos, ao nosso tempo, e por isso profundamente incômodos para os humanistas remanescentes. ${ }^{22}$

Saramago alerta para a ameaça deste novo ser cujos contornos já parece identificar nas entrelinhas da poética do "homem que nunca foi" ${ }^{23}$, o humano que já não se reconhecia assim, e que duvidava de si mesmo em textos repletos de afirmações sintonizadas com a filosofia sci-fi: "Serei eu, porque nada é impossível/Vários trazidos de outros mundos/E num mesmo ponto espacial sensível/Que sou eu, sendo eu por estar aqui?/Serei eu, porque todo pensamento/Podendo conceber, bem pode ser/Um dilatado e múrmuro momento/De tempos-seres, de quem sou o viver?”.

Talvez por isso seja ao mestre do fantástico latino-americano, Jorge Luis Borges, (e não a Camões) que Saramago vai buscar, em seu romance assassino, a "filiação" literária de Pessoa; pondo-o, na figura de um de seus duplos (Ricardo Reis), a ler The god of the labyrinth, livro imaginário de Herbert Quain, personagem do conto "Exame da obra de Herbert Quain", de Fiç̧ões. Alegação já reclamada por Emir Monegal, no artigo "Jorge Luis Borges, autor de Fernando Pessoa"; mas relativizada por Teresa Rita Lopes, no artigo "Jorge Luis Borges, amigo de Fernando Pessoa e viceversa" e finalmente negada pelo próprio Borges, que a dispensa dos jogos de poder e hierarquia, reduzindo-a a uma equilibrada fraternidade, em carta póstuma escrita ao poeta: "O sangue dos Borges de Moncorvo e dos

${ }^{22}$ A respeito dos heterônimos, por exemplo, Pessoa afirmava que: "Se me disserem que é absurdo falar assim de quem nunca existiu, respondo que também não tenho provas de que Lisboa tenha alguma vez existido, ou eu que escrevo, ou qualquer coisa que seja.”. Curiosamente, são essas palavras que Saramago coloca em epígrafe no seu romance $O$ ano da morte de Ricardo Reis.

${ }^{23}$ Referência à publicação editada por George Monteiro, The man who never was: essays on Fernando Pessoa. Gávea Brown: Rhode Island, 1982. 
Azevedo sem geografia podem me ajudar a te compreender, Pessoa. (...) Escreveste para ti, não para a fama. Juntos, compartilhamos teus versos, deixa-me ser teu amigo.".

O que é interessante na disputa Pessoa/Saramago reside aí: na interpretação conflitante e complementar que ambos fazem da modernidade - a partir de uma percepção conjunta e irrefutável da reformulação do humano - que se traduz em discursos aparentemente opostos: o entusiasta e o nostálgico. E nem sempre são discursos absolutistas, porque há muita nostalgia em Mensagem, assim como há alguma celebração, por exemplo, no Conto da ilha desconhecida de Saramago.

Mas onde Pessoa vê a expansão da mente e a possibilidade de libertação do jugo da matéria; Saramago, como um autêntico "Neo"24 português (mas um neo-Velho do Restelo), insiste nas dores e sofrimentos demasiadamente humanos, resultantes do modo devastador e indiferente como as conquistas científicas e tecnológicas parecem varrer a história, devorando os seus personagens em função de interesses pouco nobres: a "glória de mandar", a "vã cobiça" já tão criticadas por Camões na época das navegações marítimas. Ao contrário de Pessoa, que tende a assumir uma perspectiva cada vez mais distanciada de particularismos, irmanandose aos Argonautas e Astronautas numa "aristocracia" do olhar que favor nenhum concede ao "bicho da Terra tão pequeno"; Saramago concentra a sua atenção nesta raça e neste momento, analisando exatamente as suas contradições.

Apesar da discordância, não há como negar que Saramago é o escritor português contemporâneo que mais flerta, e flerta seriamente, com

${ }^{24}$ Neo é o protagonista da trilogia de filmes Matrix, dos irmãos Wachowski, baseada no livro Neuromancer, de William Gibson. A história explora as aptidóes de Neo para manipular a nova realidade simulada pelo computador, e sua missão messiânica como o salvador da humanidade agora refém das máquinas. A lenda de Matrix poderia ser considerada, portanto, uma versão pós-moderna do messianismo, à semelhança do sebastianismo português em torno d'O Encoberto, que inspira a Mensagem pessoana. 
a ficção científica, como já têm constatado por diversas vezes os críticos do gênero. Robert Silverberg, em sua coluna "Reflections" da revista americana Asimov's Science Fiction, publicou em 2001 o artigo "Causa e efeito" no qual diz: "Acabei há pouco tempo de ler um romance espantoso de FC escrito por um escritor cujo trabalho é provavelmente desconhecido para a maioria de vocês: o português José Saramago. O romance intitula-se Ensaio Sobre a Cegueira e é um exemplar assombroso da ficção científica social de Asimov: um exame das conseqüências sociais de um único desvio aterrador da nossa realidade." Jorge Candeias, no ensaio "José Saramago: O Nobel da Ficção Científica”, publicado na revista Bang! n. ${ }^{\circ}$ 0, conclui que o único romance deste autor passível de pertencer ao gênero seria Ensaio sobre a cegueira, de 1995. Em "A cegueira e o saber", Affonso Romano de Sant'Anna comenta, inclusive, haver consultado o escritor sobre as suas prováveis influências nesta área, adquiridas na leitura de autores como $\mathrm{H}$. G. Wells, por exemplo. Saramago nega, mas Romano conclui que "um estudo comparativo entre o conto "O país dos cegos" e aquele romance seria enriquecedor". Aproveito para lembrar, pois, o estudo que escrevi a respeito, intitulado "Ensaios sobre a cegueira: Baudelaire, Brueghel, H. G. Wells e José Saramago" "25, que estabelece, entre outras comparações, aquela sugerida pelo professor.

Roberto de Sousa Causo, porém, admite que "há mais quanto à presença do fantástico em Saramago, seja ele sob a forma de realismo mágico ou de fantasia histórica - como é o caso de Memorial do Convento, de 1982." Situado no século XVIII, o romance discute o papel da fantasia na base do pensamento científico, através de personagens luminares como a jovem vidente Blimunda, cujo olhar atravessa objetos sólidos e percebe vontades secretas; e o padre Bartolomeu Lourenço de Gusmão, nascido em Santos, no Brasil, e também pioneiro (como o Santos Dumont que homenageia) da aviação mais leve que o ar, com o seu invento maquínico movido a sonhos: a passarola.

${ }^{25}$ FERREIRA, 2004. 
Nesta perspectiva de análise seria possível concluir que os romances recentes de Saramago tendem a retratar, de maneira distópica, uma época de transformações em que nada existe para ser celebrado, numa oposição frontal ao entusiasmo pessoano e utópico com as conquistas da humanidade. As inquietaçôes de Saramago resultam exatamente do seu apego à forma humana e aos discursos humanistas, postos em xeque por Fernando Pessoa. Por isso, para Saramago, o progresso científico e tecnológico é visto de forma sombria e ameaçadora, resultando mais em perdas que em ganhos. Em Ensaio sobre a cegueira, os personagens perdem a vista, sinal de um tempo em que todos parecem estar cegos. Em $A$ caverna, artesãos perdem o emprego, incapazes de sobreviver à sociedade de consumo. Já em $O$ homem duplicado, escrito numa época de intensa discussão sobre a clonagem genética, ele constrói uma fição extraordinária, apoiada numa questão extremamente atual e inquietante: a perda de identidade no mundo globalizado, também tematizada no romance Todos os nomes.

A lista seria grande, mas a raiz residiria no início mesmo de sua formação, na fase nebulosa em que o autor oscila entre a poesia, a crônica, o teatro, a biografia e o conto. É nesta época, situada nas décadas de 60 e 70 , que a tendência especulativa se insere nas publicaçôes saramaguianas, a se julgar pelos títulos das obras "Provavelmente alegria", "Os poemas possiveis" " "Deste mundo e do outro". Neste livro, uma reunião de crônicas publicadas pela primeira vez no jornal A Capital, entre 1968 e 1969, encontram-se "efabulaçôes de tipo onírico", como diz Maria Alzira Seixo, "que hesitam entre a vocação para um destinatário infantil e uma acentuada propensão do escritor para os domínios do maravilhoso e do fantástico que mais tarde veremos concretizar-se melhor na sua restante obra". ${ }^{26}$ Nesses textos, Saramago revela suas impressões sobre o progresso, mas parece particularmente preocupado com as viagens espaciais:

${ }^{26}$ SEIXO, 1987, p. 22-25. 
Daqui por um mês chegaremos à lua. Mas quando e como chegaremos nós ao espírito de uma criança que pinta a neve preta porque a mãe lhe morreu? (In: "A neve preta”)

De resto, agora que os homens vão descer na lua, andar sobre ela, também sei que não senhor, a lua não perderá mistério, nem sequer para os que lá forem e de lá voltarem. Não será roubada aos poetas e aos namorados. Saber que estão lá dois homens, ou duzentos, ou dez mil - tira alguma coisa à profundidade do luar? (In: "A lua que eu conheci")

Foi assim que eu vi a primeira alunagem. Decidiu ela que a viagem à lua não fora um salto no espaço, mas um salto no tempo. Os astronautas, lançados no espaço, haviam caminhado ao longo do fio do tempo e pousado outra vez na terra, não a terra que conhecemos, branca, verde, morena e azul, mas a terra futura, uma terra que ocupará ainda a mesma órbita, circulando à volta de um sol apagado - morta ela também, deserta de homens, de aves, de flores, sem um riso, sem uma palavra de amor. Um planeta inútil, com uma história antiga e sem ninguém para a contar. (In: "Um salto no tempo") ${ }^{27}$

As leituras de autores do gênero ficção científica como Ray Bradbury, Isaac Asimov, H.G. Wells e Aldous Huxley, quando não confessas, aparecem nas entrelinhas dessas crônicas, e talvez venham a influenciar os livros que se seguem, como O ano de 1993 (1975), a noveleta "Coisas", da coletânea Objecto Quase (1978), insistindo numa temática já esboçada em alguns poemas, como "Science Fiction I", de Ospoemas possiveis (1966):

\section{Science-fiction I}

Talvez o nosso mundo se convexe

Na matriz positiva doutra esfera.

Talvez no interespaço que medeia

Se permutem secretas migrações.

${ }^{27}$ SARAMAGO, 1997. 
Talvez a cotovia, quando sobe,

Outros ninhos procure, ou outro sol.

Talvez a cerva branca do meu sonho

Do côncavo rebanho se perdesse.

Talvez do eco dum distante canto

Nascesse a poesia que fazemos.

Talvez só amor seja o que temos,

Talvez a nossa coroa, o nosso manto. ${ }^{28}$

Com esses versos genuinamente especulativos, reiteradamente introduzidos pelo advérbio "talvez", e altamente sintonizados com as pesquisas mais recentes no campo da física e da astronomia, Saramago elenca temas complexos, muitos deles já sugeridos na exótica poesia pessoana. São temas caros à literatura de ficção científica, como a idéia de universos especulares e paralelos ("Talvez nosso mundo se convexe/ $\mathrm{Na}$ matriz positiva doutra esfera") e a de viagens no tempo através de "buracos de minhoca" ("Talvez no interespaço que medeia/Se permutem secretas migrações"); abordados de forma a concluir, com a sua ironia de sempre, que toda a majestade dessas teorias nada seria sem o amor. $\mathrm{O}$ mesmo amor que prega ao Astronauta indiferente às pequenas e grandes tragédias cotidianas da Terra: "a fome, a miséria, o luto, e outra vez a fome". Além da constatação, sempre presente, de que os bons propósitos das descobertas científicas quase sempre caminham ao lado dos propósitos ditados pelo fraco desenvolvimento espiritual da humanidade, que tudo transforma em máquinas de poder, de subjugação e de morte, e que certamente o leva a apontar em seu poema a incongruente convivência histórica dos foguetes espaciais e das bombas de napalme.

${ }^{28}$ SARAMAGO, 1998. 


\section{O ano de 1993}

Nebuloso desde a sua apresentação, este livro de poemas que transbordam do lírico para o épico, ou de micronarrativas que transbordam do épico para o lírico, é o único de Saramago que se projeta, deliberadamente, num tempo futuro. Publicado originalmente em 1975 - quando 1993 ainda se situava num incerto amanhã -, O ano de 1993 traz em si o impacto da Revolução dos Cravos, que um ano antes derrubara a ditadura salazarista em Portugal. Naquele momento de inflexão, Saramago expressava numa parábola singular suas inquietaçóes quanto ao futuro da humanidade. Uma parábola que guardaria em si os gérmens de várias obras posteriores, na forma de fantasia poética.

O livro se compõe de quadros ou instantâneos de uma história distópica sobre uma civilização altamente controlada, acuada entre muros, que é invadida por seres não-humanos. Chama a atenção o caráter mutante dos personagens e as constantes trocas que estabelecem entre si e com o meio que os cerca. A indecisão sobre a natureza dos seres é uma constante, já que não se sabe quem são os homens e quem são as feras; ou o que é ser homem e o que é ser fera; para depois se descobrir que nem as feras o são realmente, pois foram convertidas em máquinas.

As forças invasoras, controladas por um cérebro eletrônico, o ordenador central - uma espécie de Grande Irmão orwelliano - travestemse na pele ora de animais selvagens, como o lobo e o elefante, ora de animais domésticos, ora de bichos peçonhentos, que se apossam alegoricamente do espaço urbano, dito civilizado, e o povoam de metáforas. Já as pessoas expulsas da cidade perambulam em hordas nômades pelos campos, desertos e montanhas. $\mathrm{Na}$ condição de feras acossadas, tornam-se seres primitivos que fogem à ameaça tecnológica buscando uma proteção tão visceral na natureza que acabam por se confundir com ela, na imagem surreal de corpos e de troncos que misturam sangue e seiva e arrancam as raízes do solo para empreender uma das primeiras caminhadas ecologicamente conscientes da literatura moderna em língua portuguesa. Civilização e barbárie se confrontam e se interrogam perigosamente, numa cidade 
tomada pela animalidade e pela selvageria e num campo que parece oferecer alguma esperança de refúgio para a humanidade, apesar dos perigos que o cercam.

Dos trinta poemas ou capítulos deste livro, consideraremos apenas dois para um breve comentário, por sintetizarem alguns dos temas mais caros da prosa saramaguiana.

\section{O diálogo com a pintura}

O primeiro texto desse livro se esboça segundo a técnica intersemiótica da ekphrasis - representação verbal de uma representação visual - que se tornará freqüente na obra de Saramago: a exemplo do quadro de Albrecht Dürer, cuja descrição inaugura o romance O evangelho segundo Jesus Cristo; ou do quadro Parábola dos cegos, de Pieter Brueghel, que orienta o desenho dos personagens perambulando pelas ruas no romance Ensaio sobre a cegueira. Parecendo seguir o impulso anunciado em Manual de pintura e caligrafia, ou seja, o de aprender a escrever pintando, Saramago abre o seu livro (capítulo ou poema primeiro) com uma suposta descrição de uma pintura surrealista de Salvador Dalí:

As pessoas estão sentadas numa paisagem de Dali com as sombras muito recortadas por causa de um sol que diremos parado

Quando o sol se move como acontece fora das pinturas a nitidez é menor e a luz sabe muito menos o seu lugar

Não importa que Dalí tivesse sido tão mau pintor se pintou a imagem necessária para os dias de 1993

Este dia em que as pessoas estão sentadas na paisagem entre dois prumos de madeira que foram uma porta sem paredes para cima e para os lados Não há portanto casa nem sequer a porta que poderia não abrir precisamente por não haver para onde abrir

Apenas o vazio da porta e não a porta

$\mathrm{E}$ as pessoas não se sabe quantas não foram contadas devem ser ao menos duas porque conversam levantam as golas dos casacos para se defenderem do frio 
E dizem que o inverno do ano passado foi muito mais doce ou suave ou benigno embora a palavra seja antiga em 1993

Enquanto falam e dizem coisas importantes como esta

Uma das pessoas vai riscando no chão uns traços enigmáticos que tanto podem ser um retrato como uma declaração de amor ou a palavra que faltasse inventar

Vê-se agora que o sol afinal não estava parado e portanto a paisagem é muito menos daliniana do que ficou dito na primeira linha

E uma sombra estreita e comprida que é talvez de uma pedra aguda espetada no chão ou de um prumo distante de porta que já perdeu companhia e por isso não atraia as pessoas

Uma sombra estreita e comprida toca no dedo que risca a poeira do chão e começa a devorá-lo

Devagar passando aos ossos do metacarpo e depois subindo pelo braço devorando

Enquanto algumas pessoas continuam a conversar

E esta se cala porque tudo isto acontece sem dor e enquanto a noite desce $^{29}$

O cenário pictórico da história confere à narrativa um caráter fantástico desde a abertura. Não se está no plano da realidade, nem no tempo histórico, mas numa projeção alienada e alienante. Salvador Dali é um "mau pintor", seus mundos são instáveis, sem consistência nem solidez. Os contornos se desfazem, forma e fundo se confundem, os conteúdos transbordam dos continentes. As figuras, liquefeitas, ora escorrem pela superfície da tela, ora se esvaziam em ruínas. Saramago parte do nonsense, mas com o desejo de restabelecer um sentido dentro do caos, daí a figura que se destaca das demais por assumir o papel de desenhista (não de desenhado). O homem que "risca no chão traços enigmáticos" é aquele que procura reescrever o seu tempo, redesenhar o seu espaço. É o homem que busca uma reinserção na história, que se nega a aceitar o imobilismo da pintura e parte para a ação. É o homem que não aceita fazer sombra sob um sol parado, mas prefere que o sol se mova - por mais

${ }^{29}$ SARAMAGO, 1987, p. 10. 
absurdo que isto seja - e a sombra o consuma por inteiro, para que possa renascer das cinzas.

Essa esperança de redenção do humano estará sempre presente nas distopias saramaguianas. Não serão elas, pois, distopias propriamente ditas, mas utopias disfarçadas. A partir deste primeiro locus, elaborado no cenário de $O$ ano de 1993, Saramago estará sempre, ao longo de sua obra, perseguindo a ilha desconhecida na qual nunca deixa de acreditar. Por isso, por mais sombrias que sejam, suas histórias se resolvem positivamente, mesmo que, às vezes, essa resolução comprometa a coerência de alguns enredos. A fé na humanidade - numa concepção específica e humanista - transcende a decepção pela constatação da falência do humano, que devasta de ponta a ponta a sua escritura, com muito mais ressentimento do que se percebe, por exemplo, em Fernando Pessoa.

A reação pessoana a essa decepção é a negação do humano. É a indiferença por um ser que precisa ser superado; é o investimento num "pós-humano", teorizado pelo filósofo Antonio Mora, cantado pela poesia heteronímica e pelo poeta do "Supra-Camões" da Mensagem, e ficcionalizado por Bernardo Soares, autor do diário íntimo de Fernando Pessoa, transformado em personagem de si mesmo num mundo sem credibilidade. Mas enquanto a ficção pessoana permanece na paisagem surrealista, trabalhando em aparente silêncio e passividade pela corrosão das formas conhecidas; a ficção saramaguiana mobiliza todos os seus esforços na luta pela reconstrução da realidade, pelo resgate da memória, pela preservação dos patrimônios, materiais ou imateriais.

Pode-se dizer que $O$ ano de 1993 é a nascente de um verdadeiro manancial simbólico de narrativas com um profundo e quase religioso teor humanista, que desemboca na foz de uma esperança sem limites na capacidade do aprendizado humano com a história. Por isso, ao se projetar no futuro, Saramago mergulha quase sempre no passado, nos documentos, nas conservatórias, nas imagens do tempo que se eternizam nas pinturas. Sua ficção especulativa não interroga o que será, mas o que poderia ter sido. Sua abordagem do passado é fundada na desconfiança, no benefício da dúvida, na aposta em alternativas. Elabora, pois, um movimento complexo 
de especulação, admitindo a possibilidade da existência de outros mundos, de outras histórias, acontecidas e não registradas, ou não registradas e por acontecer. À diferença de Fernando Pessoa, que nada mais interroga porque já não comunga com os seus pares no presente, e morre com a certeza de uma constatação que seria a própria antítese do impulso gerador da ficção científica: "I know not what tomorrow will bring".

\section{A consciência ecológica}

Como agente de um mundo em transformação que se deseja preservar para o benefício de seus habitantes, Saramago não poderia se furtar à questão ecológica. A preocupação com a agressão ambiental resultante do progresso e dos avanços tecnológicos é um assunto que mobiliza a ficção científica e fornece muito material à especulação. Embora a questão seja tocada tangencialmente na prosa saramaguiana, o animal é um elemento decisivo na construção de seus enredos, podendo vir até mesmo a protagonizar suas histórias, como é o caso de seu romance mais recente, $A$ viagem do elefante.

No livro $O$ ano de 1993 o papel dos animais é fundamental, ao lado das máquinas e dos homens. A discussão não caminha, porém, na direção do discurso pós-humanista, que encara os desafios contemporâneos da ciência reformuladora dos corpos e investiga as consequiências da crescente promiscuidade do orgânico com a tecnologia na geração de seres humanos híbridos ou cyborgs. Não se considera, por exemplo, que os seres humanos e as máquinas estariam se aliando não apenas porque os humanos convivem, interagem e se integram cada vez mais às máquinas, mas sobretudo porque as máquinas estão ficando cada vez mais parecidas com os humanos.

Na ficção de Saramago, a discussão caminha no sentido da reação, da revolta social, da vingança contra os poderosos: essa entidade não definida que invade a cidade, se apropria do poder e inflige sofrimento aos habitantes, caracteristicamente humanos. Os humanos não se misturam com as espécies "animais" ou "mecânicas" nessa história. Apenas 
na conclusão, um casal de resistentes tem seus corpos fundidos ao tronco de uma árvore, estabelecendo uma simbiose com o mundo vegetal com objetivos estratégicos num contexto de guerra.

A apropriação literária dos animais em $O$ ano de 1993 persegue três caminhos: o da inversão de papéis - quando os animais domesticados, enquanto personagens, tornam-se agressivos com os humanos, revoltandose contra a dominação; o da alegoria - quando os perseguidores e torturadores dos humanos (cuja natureza não é definida, mas supõe-se ser maquínica) são identificados com animais repulsivos ou peçonhentos (ratos, cobras, aranhas); e o da metáfora - quando os humanos são tomados, simbolicamente, como feras, seja num sentido negativo (os lobos que dominam a cidade e saem à noite para caçar as pessoas foragidas, de maneira sangrenta e similar às caçadas humanas de animais); seja num sentido positivo (os excluídos da cidade que passam a viver como as feras na natureza, tomadas como seres em sua liberdade e inocência original).

A questão torna-se mais complexa quando tanto os bichos rebeldes quanto as feras metafóricas aparecem, na segunda metade do livro, como seres híbridos, cyborgs animais. $\mathrm{O}$ mal, portanto, não estaria nos bichos, mas nas máquinas que os corromperam e que deles se apropriaram. Os mitos do bom selvagem e do jardim das delícias são perpetuados em detrimento do mal tecnológico. Ao redimir os animais no contexto de sua apropriação literária, Saramago parece revelar uma aguda sensibilidade para com os direitos dos seres ditos "inferiores ao homem", tão desqualificados no ensaio de Antonio Mora. Veja-se o trecho, extraído do capítulo/poema 17:

A mais terrível arma da guerra do desprezo foi o elefante

Porque então haviam os ocupantes da cidade desdenhado perseguir nos campos as hordas assustadas dos homens que se arrastavam entre céu e céu Todos os animais do jardim zoológico foram paralisados por acção de misturas químicas nunca antes vistas

E ainda vivos abertos sobre grandes mesas de dissecção esvaziados de entranhas e do sangue que jorrou por fundos canais para o interior da terra donde apenas saía para certos banhos das prostitutas principais Desta maneira tornados pele massa muscular e esqueleto foram os 
animais providos de poderosos mecanismos internos ligados aos ossos por circuitos electrónicos que não podiam errar E estando tudo isto no comprimento de onda do ordenador central foi nele introduzido o programa do ódio e a memória das humilhações Então abriram-se as portas da cidade e os animais saíram a destruir os homens Não precisavam de dormir nem comer e os homens sim

Não precisavam de descanso e o mais que o homem sabia era terror e fadiga Foi essa guerra chamada do desprezo porque nem sequer o sangue lutava contra o sangue

Já foi dito que o elefante era a mais terrível máquina daquela guerra Talvez quem sabe porque havia sido muitas vezes domesticado e ridicularizado nos circos quando a sua grande estatura se equilibrava numa bola absurda ou se levantava nas patas traseiras para cumprimentaro público Entretanto o maior dos sábios do ocupante insiste em afirmar que háde fazer rir o ordenador hipótese que não surpreenderá tendo em conta os factos relatados ${ }^{30}$

É inegável a semelhança deste trecho com o enredo do romance $A$ ilha do doutor Moureau, de H.G. Wells: história de um médico que, exilado numa ilha tropical, manipula corpos de animais em experiências monstruosas de vivissecção - atividade defendida pelo filósofo pessoano Antonio Mora, com a sua frieza científica pós-humana, e condenada como crime por Saramago em seu texto. Moreau é um cientista obcecado pela idéia de transformar animais em homens através de hipnose e de cirurgias reconstrutoras efetuadas sem anestesia. A manipulação das vontades das criaturas resultantes de tais experiências pelo medo e pela dor, contudo, nos leva a pensar que o objetivo de Moureau, na verdade, era o de satisfazer sua ânsia de poder. Suas motivações parecem menos científicas e filosóficas do que políticas, uma vez que os seus interesses recaem mais sobre a pesquisa de mecanismos de subjugação e de dominação do que propriamente na dúvida sobre a natureza do humano.

Talvez por isso a referência seja tão oportuna para Saramago. Mas enquanto Wells não hesita em especular sobre simbioses viscerais entre os

${ }^{30}$ SARAMAGO, 1987, p. 65. 
humanos e os bichos, Saramago mantém os humanos intocados na sacralidade de seus corpos. Apenas os bichos são submetidos a experiências indignas e abjetas, transformados em carcaças manipuladas por sensores eletrônicos e forçados a uma aliança com as máquinas para uma guerra contra a humanidade; uma guerra na qual parecem exercer não um papel libertário de sua espécie, mas uma extensão do mesmo papel escravizado que vêm exercendo há eras. A revolução dos bichos na ficção saramaguiana é ideologicamente confusa, pois não se trata de uma guerra voluntária, posto que nem o ódio contra os homens atribuído aos animais é genuíno - trata-se de um programa de computador inoculado em suas mentes. Ao contrário de se constituir numa defesa dos fracos e oprimidos, como se esperaria de um legítimo discurso humanitário, portanto, a ficção de Saramago acaba revelando, inadvertidamente, uma postura profundamente antropocêntrica e controladora, tão impermeável ao ponto de vista alheio quanto a postura do narrador camoniano ao enaltecer as grandezas imperialistas portuguesas.

Diante disso, o discurso de Antonio Mora parece mais legítimo e verdadeiro, quando não mais eficiente na denúncia dos horrores de que é feita a alma humana do que o compungido e revoltado discurso do narrador de $O$ ano de 1993. Nas melhores intençóes residem as motivações mais ocultas e desconhecidas, quase sempre parciais e sectárias. Daí, talvez, porque Alberto Caeiro chora ao ouvir o discurso do "homem das cidades":

Ontem à tarde um homem das cidades

Falava à porta da estalagem,

Falava comigo também.

Falava da justiça e da luta para haver justiça

E dos operários que sofrem,

E do trabalho constante, e dos que têm fome,

$\mathrm{E}$ dos ricos, que só têm costas para isso.

E, olhando para mim, viu-me lágrimas nos olhos

E sorriu com agrado, julgando que eu sentia

${ }^{31}$ PESSOA, 1986, p. 154. 
O ódio que ele sentia, e a compaixão

Que ele dizia que sentia.

(Mas eu mal o estava ouvindo...) $)^{31}$

E daí, também, provavelmente porque Ricardo Reis deixa-se embeber no seu jogo de xadrez enquanto ocorre não sei qual guerra na Pérsia, a invasão arde na Cidade e as mulheres gritam, postas contra os muros caídos e violadas, ou reagindo à violação "quando o ódio entra enfim em seus corpos", como na guerra de 1993. Indiferente apenas às açóes inúteis e equivocadas dos homens, mas profundamente atento ao jogo, haja ou não parceiro - e antes de ser assassinado pelo romance de Saramago -, ele comenta, com a sua infinita sabedoria pós-humana ou cyborg:

(...)

Passamos e agitamo-nos debalde.

Não fazemos mais ruído no que existe

Do que as folhas das árvores

Ou os passos do vento.

Inutilmente parecemos grandes.

Salvo nós nada pelo mundo fora

Nos saúda a grandeza

Nem sem querer nos serve.

Se aqui, à beira-mar, o meu indício

$\mathrm{Na}$ areia o mar com ondas três o apaga,

Que fará na alta praia

Em que o mar é o Tempo? ${ }^{32}$

32 PESSOA, 1986, p. 198. 


\section{Referências bibliográficas}

CAMÕES, Luis Vaz de. Os lusíadas. Porto: Porto Editora, [s.d.].

CAUSO, Roberto de Sousa. Fiç̧ão cientifica, fantasia e horror no Brasil. Belo Horizonte: Editora da UFMG, 2003.

COSTA, Horacio. José Saramago. O periodo formativo. Lisboa: Editorial Caminho, 1997.

DELEUZE, Gilles. Como criar para si um corpo sem órgãos. In: DELEUZE; GUATTARI. Mil platôs. Capitalismo e esquizofrenia. v. 3. São Paulo: Editora 34, 2007.

FERREIRA, Ermelinda. Ensaios sobre a cegueira: Baudelaire, Brueghel, $\mathrm{H}$. G. Wells e José Saramago. In: Leituras: autores portugueses revisitados. Recife: Edufpe, 2004.

FOUCAULT, Michel. As palavras e as coisas. São Paulo: Martins Fontes, 1999.

HARAWAY, Donna. Um manifesto para os cyborgs: ciência, tecnologia e feminismo socialista na década de 80. In: HOLLANDA, Heloísa Buarque de. Tendências e impasses. Rio de Janeiro: Rocco, 1994.

HAYLES, Katherine. How we became posthuman. Virtual bodies em cybernetics, literature and informatics. Chicago and London: The University of Chicago Press, 1999.

LYOTARD, Jean-François. O inumano. Consideraçôes sobre o tempo. Lisboa: Editorial Estampa, 1997.

PESSOA, Fernando. Obra poética. Rio de Janeiro: Nova Aguilar, 1986.

PESSOA, Fernando. Obras em prosa. Rio de Janeiro: Nova Aguilar, 1986.

SÁ-CARNEIRO, Mário de. Obra completa. Rio de Janeiro: Nova Aguilar, 1995.

SANTAELLA, Lucia. Culturas e artes do pós-humano. São Paulo: Paulus, 2003. SANT'ANNA, Afonso Romano de. A cegueira e o saber. Rio de Janeiro: Rocco, 2006.

SANTOS, Jair Ferreira dos. Breve, o pós-humano. Rio de Janeiro: Francisco Alves, 2002. 
SARAMAGO, José. O ano de 1993. Lisboa, Editorial Caminho, 1987.

SARAMAGO, José. Deste mundo e do outro. Lisboa: Editorial Caminho, 1997.

SARAMAGO, José. Os poemas possiveis. Lisboa: Editorial Caminho, 1998.

SEIXO, Maria Alzira. O essencial sobre José Saramago. Lisboa: Imprensa Nacional-Casa da Moeda, 1987.

SIBILIA, Paula. O homem pós-orgânico. Corpo, subjetividade e tecnologias digitais. Rio de Janeiro: Relume-Dumará, 2002.

WELLS, H. G. A ilha do doutor Moreau. Lisboa: Mem Martins, [s.d.].

WOLFE, Cary (Ed.). Zoontologies. The question of the animal. Minneapolis and London: The University of Minnesota Press, 2003.

\section{Resumo}

Embora considerada um gênero menor e de massa, a ficção científica tem inspirado alguns autores clássicos e eruditos da literatura em língua portuguesa. Neste trabalho, investigamos aspectos da poesia de Fernando Pessoa e da narrativa de José Saramago, procurando reler comparativamente algumas idéias fulcrais de suas produções à luz de reflexôes sobre conceitos do pós-humanismo que problematizam as artes, as ciências e a tecnologia no mundo contemporâneo.

\section{Abstract}

Science fiction has inspired some classical and erudit authors in portuguese literature, in spite of being considered a minor, mass gender. This essay tries to discuss comparatively some aspects of the poetry of Fernando Pessoa and the novels of José Saramago in order to understand the ideas in their works, related to the concepts of posthumanism, that reflects about the arts, sciences and technology in nowadays world. 